\title{
Exploring Effective Academic Governance at a Canadian University
}

Patrick Lougheed

Plaid Consulting

Michelle Pidgeon

Simon Fraser University

\begin{abstract}
In Canada, only $44 \%$ of members of academic governance bodies at universities feel that their boards are effective decision-making bodies (Jones, Shanahan, \& Goyan, 2004). In this study, we examined the views of senators at a British Columbia university regarding their senate's effectiveness in decisionmaking, including structures, processes, and leadership, and their suggestions for potential changes. Eight interviews were conducted with current or recent former senators in May 2012; each interview lasted 30 to 60 minutes. At the time of the interviews, fewer than half of the senators stated that the senate was effective, with concerns concentrated in the areas of committees, participation of faculty and students, and level of debate. This research has implications for enhancing the effectiveness, legitimacy, and credibility of institutional academic governance structures and processes, particularly in the Canadian context.
\end{abstract}

\section{Résumé}

Au Canada, seulement $44 \%$ des membres des instances de gouvernance universitaire estiment que leur conseil est compétent dans sa capacité décisionnelle (Jones, Shanahan et Goyan, 2004). La présente étude a examiné les différents points de vue des membres du conseil d'une université de la Colombie-Britannique en ce qui concerne son efficacité décisionnelle quant aux structures, aux processus et au leadership de l'université. On leur demandait aussi leurs suggestions quant aux changements qu'ils apporteraient à leur conseil. C'est ainsi qu'en mai 2012, huit entrevues d'une durée de 30 
à 60 minutes chacune ont été menées auprès des membres du conseil de cette université, dont certains sont toujours en poste aujourd'hui. En plus de relever des inquiétudes portant surtout sur les comités, la participation des professeurs et des étudiants, et le niveau des débats, l'étude révèle que moins de la moitié des membres interrogés jugeait le conseil efficace au moment de l'entrevue. Ainsi, la présente recherche pourrait améliorer l'efficacité, la légitimité et la crédibilité des structures de gouvernance universitaires, ainsi que les processus institutionnels, en particulier dans un contexte canadien.

\section{Introduction}

It is easy to point at something and say "it's broken," but it is another matter to understand what we mean by "broken" and how to fix it. There is developing consensus that the university senate as it exists in Canada has problems-including lack of strategic focus (Bradshaw \& Fredette, 2009), diversion of authority to senior administration, few meaningful conversations and debates (Berkowitz, 2010), and a negative view of senate effectiveness (Jones, Shanahan, \& Goyan, 2004) - but what should we do about them?

The current governance arrangements that are widely used in Canada have their roots in the Flavelle Commission of 1905-06, which recommended splitting the academic and financial governance of the University of Toronto between two separate bodies. The Commission sought to insulate the University from the political whims of government by creating a corporate board appointed by, but separate from, the government, while balancing the public and academic interests between two distinct structures within the overall framework of the institution (Province of Ontario, Royal Commission on the University of Toronto, 1906). This bicameral arrangement has become the dominant model at most universities in Canada, with only a small number of institutions using alternative structures (Jones, Shanahan, \& Goyan, 2001).

Within a bicameral governance model, one half is the academic governance body, usually referred to as the senate (the term we'll use throughout) or general faculties council. While the specific arrangements and powers of the senate vary by jurisdiction and institution, they are generally dominated in numbers by members of the institution's faculty, and senate powers often include: setting admission standards; setting the curriculum and requirements for graduation; overseeing examinations and evaluations; setting academic policy; conferring degrees; establishing and overseeing financial aid; and overseeing student discipline (Jones et al., 2004). At some institutions, senates have additional responsibilities, including overseeing library policy and recommending appointments to the corporate board (Jones et al., 2004). The other half of the bicameral model is the financial governance body, usually referred to as the board of governors. The board is responsible for the financial and management affairs of the university, including setting and overseeing the university budget and human resources (Jones et al., 2001; University Act, 1996).

Trakman (2008) argues that many institutions are in the midst of crises of confidence and that governing boards must be agents of change, concluding that "good" governance does not simply happen but requires substantial effort to determine the best set of processes and structures for each crisis, specific to the context of the institution. "Ultimately, governance models are created by people to govern people. They are only as good as they who devise and apply them, as well as those who live by them" (Trakman, 2008, p. 77). 
Additional research, both within and external to Canada, has concluded that the context of governance structures is incredibly important and what works at one institution is not guaranteed to work at another (Ackroyd \& Ackroyd, 1999; Minor, 2003; Trakman, 2008).

In this article, we put forth the question regarding perceptions of senate effectiveness from the viewpoint of its members, within the context of a university in British Columbia. Before exploring the question and responses in depth, we will provide a more detailed discussion of the literature.

\section{Understanding Senate Effectiveness}

There has been little research conducted on the bicameral governance structure in higher education, particularly within the Canadian context, that explores the experiences of board members and senators and their perceptions of this model's effectiveness. Of the research that has been conducted, emerging themes include: roles and responsibilities; senate structures and processes; and effectiveness.

\section{Roles and Responsibilities}

As discussed earlier, Jones et al. (2004) not only articulated the roles and responsibilities of senates in their two-phase survey; they also found significant differences in the roles filled by senates at different institutions-for example, while more than $75 \%$ of senates set admissions standards, oversee education policy, and confer degrees, the roles of library oversight and recommending senior appointments to the board were within the purview of only a minority of senates. In terms of who makes up the senate, the majority of senators represented faculty, however, the percentage of faculty senators was significantly less than half, which is surprising for an academic oversight board.

The Jones et al. (2004) survey was the basis of follow-up work conducted by Pennock Jones, Leclerc, and $\mathrm{Li}$ (2015) in 2012, which used a slightly modified version to determine what changes had occurred in the landscape in the 12 years since the original survey. Between the two surveys, there were improvements in some measures, particularly around orientation sessions for new senators and perceptions of senate effectiveness, which rose to roughly 50\%. The survey also showed reductions in the number of committees at most institutions, where committees had been eliminated in an attempt to rationalize structures and improve senate effectiveness.

Birnbaum (1989) suggested that senates fill roles that are both manifest/planned and latent/unplanned within institutions, and that awareness of the latent functions is critical if any changes are to be made to senates, such as reform or dissolution.

\section{Senate Structures and Processes}

In the Canadian context, the reflections of a former senate chair at York University provided the basis for Bradshaw and Fredette's (2009) examination of the changes needed to ensure that academic governance retains an effective function in the modern university. From their analysis, the authors argued that current governance processes are largely internally-focused, short-term, operational, reactive, and simplistic. By moving towards a model that allows for a senate that is strategic, proactive, integrated, and cohesive, institutional governance can become more effective (Bradshaw \& Fredette, 2009). 
Governance processes are inherently tricky and can be easily derailed by lack of trust and political maneuverings, while allowing for gaps and silences where there is little or no oversight (Bradshaw \& Fredette, 2009).

Elsewhere, Ackroyd and Ackroyd (1999) reviewed university governance in Britain, concluding that different structures yield different results and that institutions must be able to adapt their governance processes to their unique circumstances. Trakman (2008) suggested that many institutions are in the midst of crises of confidence and that governing boards must be agents of change, concluding that "good" governance does not simply happen but requires substantial effort to determine the best set of processes and structures for each crisis, specific to the institution's context. Therefore, legitimacy in governance decision making is about the process, as Hartley (2003) found in a study conducted at a small US liberal arts college where legitimacy decided the success or failure of a change task force that bypassed the senate.

\section{Effectiveness}

Minor (2003) used a number of factors to create a framework of senate effectiveness based on a survey of 750 institutions in the United States, looking at institutional cultural characteristics, such as trust, communication, involvement, and participation, along with the functional roles of senate. While predictive models that mapped the factors to the result and evaluated most senates as moderately effective were created, Minor concluded that the focus must be on addressing the known challenges to senate effectiveness.

Jones and Skolnik (1997) surveyed governing boards of every provincially-supported university in Canada in 1994-1995 in two parts: the first surveyed the board secretaries to determine makeup and policies of the boards, while the second surveyed the board members themselves. The authors found that most board members believed their boards functioned well, though they indicated that the boards could be more effective in their lobbying of governments.

Building on the board-based work of Jones and Skolnik (1997), Jones at al. (2004) conducted a two-phase study with senate secretaries and senators across Canada between 1998 and 2000. They found that senates spent relatively little time assessing their performances and that there was a divergence of opinions on the roles senates should and do play between constituencies, such as senior administration, faculty, and students.

One of the most interesting findings across the Canadian studies (Jones et al., 2004; Pennock et al., 2015) was the response from senators regarding whether their senate is an effective decision-making body, to which only $44 \%$ of senators responded positively in 1998-2000 (Jones et al., 2004), and 50\% responded positively in 2012 (Pennock et al., 2015). Responses to related questions revealed similarly split opinions: $60 \%$ stated that their senate primarily approved decisions that had already been made, $68 \%$ agreed that it was difficult for their senate to make decisions involving significant change, while $65 \%$ stated that their senate provided an important forum for significant discussions (Jones et al., 2004, pp. 56-57). Pennock et al. (2015) provided a breakdown of responses to the effectiveness question by constituency, with a majority of senior university administrators, graduate students, and external members generally indicating that their senate was effective, but only a minority of faculty, undergraduate students, and university support staff felt the same way. 
The work done by Jones et al. (2004) and Pennock et al. (2015) in creating a national dataset of information on senates and the perceptions of senators is incredibly important. However, application to any particular context is limited, as the data is presented only at a national level and the participating institutions were not identified. While the same survey has now been repeated to get an idea of changes over time in the Canadian context, looking at issues in-depth or at applications in particular institutional contexts has not been done. Informed by the 2004 work of Jones et al., our research study data was collected in 2012, at which time the follow-up survey by Pennock et al. (2015) was also in progress. It is necessary to present the context of the research before elaborating on its design.

\section{Research Design}

\section{Context}

This research took place at a university in British Columbia. The institution operates under a bicameral governance model mandated by the province's University Act (1996) and has a senate comprising 68 senators from four broad groups: 16 administrators sitting ex officio, 32 faculty members, 16 students, and 4 members of convocation (generally alumni). The senate also includes more than 20 committees and the institution has a board of governors with 15 members. The term of membership for elected (non-ex officio) senators is either one year (for student senators) or three years (for other elected senators). For the purposes of this study, and to protect the identities of the participants, we are referring to the university as the institution.

\section{Purpose and Research Questions}

The applicability of the Jones et al. (2004) survey results to the institutional context surveyed in this research is unknown. The institution may or may not have participated in the initial phase of either survey, and the senators may or may not have participated in the second phase. Even if the institution and the senators of the day had participated, factors such as turnover in elected and ex officio senators, modification to the institution's vision, mission, or direction, and the small proportion of the overall survey responses from the institution mean that taking away any current, local knowledge is impossible.

Based on the previous national work on governance (i.e., Jones et al., 2004 and Pennock et al., 2015) and a desire to research the experiences of senators within one institutional context, we set out to investigate current and recent senators' perceptions of the effectiveness of the institution's senate and what changes they felt could increase its effectiveness. There were two primary questions:

1. What are the senators' perceptions of the effectiveness of the senate?

2. What changes could be made, from the senators' points of view, to improve the effectiveness of the senate?

\section{Participants}

Our research targeted members of the institution's senate who served in the 20092010 and 2010-2011 senate years. In order to ensure that participants had a reasonable amount of time to participate in the senate and form an opinion, only those with a 
minimum of one year of experience within the selected timeframe were invited. During the identified two-year period, a total of 98 individuals served on the senate. Of these, 75 had served for one year or more during the two-year timeframe. From publicly available information, we obtained email addresses for 64 of these members, who were sent letters of invitation to participate in this study. Of these, 10 responded positively, and eight were ultimately interviewed. The interviewees consisted of two ex officio senators, four faculty senators, one convocation senator, and one student senator. There was at least one participant from each broad category of senators, and the participants are roughly representative of the senate's overall makeup, with students slightly under-represented (largely reflective of the fact that their contact information was less likely to be publicly available and therefore it was difficult to include them in invitations to participate) and convocation senators over-represented compared to their relatively small numbers on the senate.

\section{Procedures and Analysis}

Given the national survey information, it was important to use a more qualitative approach due to the context and nature of the research questions. The interviews were semi-structured to allow the senators to express their perceptions in their own way, and to allow the interviews to explore particular aspects of the responses as necessary. Interviews ranged from 30 to 60 minutes and were scheduled at a time and location that was convenient to the participant.

After the interview recordings were transcribed, the interviews were analyzed using a thematic analysis approach (Creswell, 2012). Overall results regarding perceptions of senate effectiveness were categorized as positive, negative, and in-between, while major themes regarding why the senate was or was not effective and how it could or could not be made effective were identified.

\section{Results}

In this article, we focus on the responses to the first of our research questions, namely senators' perceptions of the effectiveness of the institution's senate and why they have that perception. We have grouped the responses into themes, and will discuss them in descending order from the most commonly discussed theme after we discuss our participants' definitions of what constitutes an effective senate and their overall perceptions of the effectiveness of the institution's senate.

\section{Definitions of an Effective Senate}

The Jones et al. (2004) survey did not define effectiveness prior to asking participants whether they thought their senate was an effective decision-making body. In an attempt to frame the lens the senators were using, and to start moving towards a view of the "ideal" senate in the institutional context, one question in our interview asked the senators how they would define an effective senate. A number of common threads ran through the senators' responses. In particular, they indicated that an effective senate would:

- have a culture that allows and encourages all members to participate and be engaged in discussion and debate (5 participants);

- be credible and relevant within the institutional community (2 participants); 
- be representative of the institutional community (1 participant);

- have a diversity of opinions (1 participant);

- allow all senators to have similar access to information (1 participant);

- have mutual respect between members (1 participant); and

- scrutinize all proposals that come before it, from the major to the minor (1 participant).

\section{Overall Effectiveness}

Responses from the eight senators interviewed indicated divergent views on senate effectiveness. Three senators indicated that the senate was effective, one answered "yes and no," while the remaining four indicated that the senate was not an effective decisionmaking body. All of the opinions were qualified in some way, with the senators expressing that effectiveness varied in different portions of the structures surrounding the senate.

Both ex officio senators responded that the senate was effective, while both the student and convocation senators indicated that the senate was not effective. The faculty senators were split-two answered negatively, one answered "yes and no," and one answered positively. The faculty senators that answered "yes and no" and positively both held administrative appointments (i.e., an appointment as department chair or above but below the level of faculty dean, which would have categorized them as ex officio members), while the two that answered negatively did not.

Participants responding positively indicated that the senate was effective because it provided a forum where issues could be discussed within a broad context with representation from a diverse range of individuals and constituencies-students, faculty, and administrators-rather than being limited to the immediate material brought to the senate. Participants also commented that meetings were well-organized and well-run. The senate was described as a "multi-layered animal" (Participant 1), in part a political forum and not simply one making decisions on academic matters; this forum provided an important opportunity for members of the community to raise a variety of issues of concern.

Participants that responded negatively often indicated that the senate's opportunity for input was too late in the process and that many of the decisions were made by senate committees or others prior to the materials being presented at the senate. There was concern that participation at the senate was too limited, with an indication that the senate had many "backbenchers" that did not contribute to the debate, often due to fear or lack of knowledge on the proper way to contribute.

Regardless of a participant's initial response, there was nearly universal agreement that not all of the committees and structures connected to senate were equally effective. Responses regarding senate processes tended to be more positive, though several suggestions for improvements were made.

\section{Senate Committees}

All eight participants commented on senate committees at some point during their interviews, indicating that the senate had a mixture of effective and ineffective committees, with particular ones being singled out as ineffective by multiple senators. Senators also commented on the role of the committee chairs and the election process for committee positions.

Sentiments regarding the effectiveness of committees was mixed. Committees with a routine flow of documents and a clear mandate from the senate were seen as the most 
effective, while committees with a more advisory role and mandates that were less clear were generally seen as the least effective. In addition, participants commented that the committees that presented materials with clearly articulated rationale, intentions, and effects were more effective than the ones where the senate needed to make changes or interpret intentions. The number of committees was commented on several times, with one participant remarking "that was one of the things I first noticed when I came here; there were committees for almost single tasks operating."

The chair's influence in ensuring that meetings and committees are run effectively was noted by several senators. With an effective chair, difficult issues could be routinely dealt with as the chair provides guidance on how to move forward; with an ineffective chair, committees could instead descend into "an absolute mess." Certain preferences for committee chairs were expressed in order to ensure faithfulness to the faculty voice in governance, particularly those committees involved in faculty-aligned areas, such as curriculum.

One senator noted that finding people willing to be on committees could be difficult due to the sheer number of committees and seats, and often resulted in filling positions by acclamation rather than election. They remarked, "I think there should be, there could be more thoughtful process, a little more reflection on how you get the right people on these committees." The challenge in finding suitable members for committees connects to the next theme of faculty senators.

\section{Faculty Senators}

In total, five participants remarked on faculty senators during their interview. Three participants remarked that many of the faculty representatives were the same over multiple terms and these senators were also nearly universally more senior (e.g., associate or full professors). These were participants who responded both positively and negatively to the effectiveness question, and were both ex officio and faculty senators.

The participants were unclear on why junior senators were not well represented in the senate and held divergent opinions. One participant remarked, "I think it's more that people are reasonably happy with the way things are, and I think people who get serious about wanting to make a change to [the institution] soon find that senate is the place to go." While lack of encouragement was also mentioned, an ex officio participant indicated that this may be connected to the tenure process. As junior faculty, those on the tenuretrack but not yet tenured (e.g., assistant rank) may be encouraged to focus on research and teaching in their tenure track years, rather than service and committee activities, in order to successfully obtain tenure.

\section{Student Senators}

Four participants discussed student senators, and while only one student senator participated in the study, this participant raised a number of significant points around the role of students on the senate. Notably, they indicated that there was a general misunderstanding on the part of students regarding the role that the senate plays. Students are typically on the senate for the shortest amount of time, have the least knowledge about institutional culture and processes, and have fewer connections that can aid and guide them. While incoming student senators are given an orientation, that orientation focuses 
on how the senate works as opposed to how to be an effective senator. Many students are on the senate for only a single term, and the lack of connections to appropriate supportsfor example, to the Secretary of the senate or another administrator familiar with the senate-means that many student senators do not participate out of fear of embarrassing themselves through lack of knowledge.

A faculty participant indicated that the institution may be trying to involve student participation at too many points in the process. While they viewed this as commendable, they also commented that there may be too small a contingent of interested and available students to fill all the roles. In their words:

I appreciate the student involvement at every level, and I think actually there's so much student involvement at [the institution] that students can't be involved because there's not enough students and enough time for students to be involved, so the irony is in trying to get lots of student involvement and lots of committees, you end up seeing the same students and burning them right out.

An example of this scenario was given by another participant. The senate requires that in each group of student senators elected there be at least three undergraduate and three graduate students, but there may not always be enough students putting their names forward for consideration to meet those minimums. Recently, there was a year where initially there was only a single graduate student senator; this student ended up in a situation where they had to fill every committee seat set aside for a graduate student senator.

\section{Size and Composition of the Senate}

The size and composition of the senate came up during interviews in three different ways. One faculty senator expressed their perception that the senate was too large, with too few members truly participating. The convocation senator expressed similar thoughts, indicating that:

The larger the meeting is, the less willing people are to speak up with any sort of view they think might not be universally shared, and the more people are likely to think 'oh, well, somebody else will have read this, so I don't need to.'

A second faculty senator indicated that one of the major senate committees exhibited how a smaller size could create a more effective group: "I think we have an effective senate, and it's [one of the senate's committees]. And the reason I think it's effective is it's not so large that you get more participation." A third faculty senator commented that the senate could benefit from representation from areas of the institution outside the academic ones. While this would necessarily expand the mandate of senate, their view was that non-academic areas, such as portions of student services, affect the academic environment and should be reflected in the institution's governance structures.

\section{Senate as Decision-Maker}

Three participants indicated that they did not feel that senate was, or was perceived as, a decision-making body. In the words of the student senator, "technically decisions are being made, but I think whether or not it is going to happen is a forgone conclusion." 
These three participants also indicated that so much work goes into items before they come before the senate, senators find themselves looking at the fine details of proposals rather than determining whether it is the right thing to do and participating in substantive discussions. An ex officio participant remarked that there is a time and a role for both the rubber-stamping and for delving deeper into the materials:

There is simply a rubber stamping role, a watch dog role ... and the fact that everybody knows that their documents are going to senate means they pay attention, and they work hard on them, and so although it sometimes seems like senate is rubber-stamping things, if it wasn't doing that, I think we would all get a lot more sloppy, so that rubber stamping role is actually important, because it does provide a public scrutiny of anything to do with changing or developing academic programs.... What I do see as more of a concern is that there's a sort of feeling around [the institution] that senate is only a rubber stamping place, and therefore people don't want to get involved in it.

\section{Review of the Senate}

The fact that there has been no review of the senate in over a decade was commented on by both ex officio participants, with a faculty senator adding the need to review the senate and senate committees on an ongoing basis. All three participants indicated that a review would provide an opportunity to look at how the senate conducts its business, the opinions of senators, and potential changes. Of note is that the two ex officio participants responded that the senate was effective, while the senator commenting on the need to review the senate responded "yes and no."

One of the ex officio senators also suggested that a senate review may benefit from being an external one-that is, one conducted by senators or others from an outside institution who were nevertheless familiar with academic governance. Previous reviews were all completed by members of the institutional community, never having "brought in experienced administrators or faculty members or for that matter even student leaders from other universities, and said, 'have a look at our senate, and what could we do better, what works for you at your institutions?"

\section{Level of Debate at the Senate}

Two participants noted that there were issues regarding the level of discussions at senate meetings. The participants desired that the senate take on a fairly high-level of discussion-whether something should be done, for example, and how to approach that-while taking editorial changes offline to be dealt with prior to meetings or in a different format. One participant remarked:

I think we're still having difficulty finding the right level of debate in the Senate chambers. Sometimes we are bogged down in my view with minutia and clerical kind of revisions to things, and sometimes we're [talking about] ideas that are so vast that many people don't have a legitimate entry point in to the conversation. So you know, when its working best is when the materials have come, and they're thoroughly researched, and at the right level and that discussion can take place, 
where people are reasonably informed and able to participate and a decision follows the discussion, that's the very best, and there's been those times where [the institution's] Senate, when it's at its worst, we're either nit-picking through documents or else having discussions that lead nowhere.

\section{Senate Processes}

The student senator indicated that mapping out the existing processes and structures would be beneficial. This would be particularly true from the perspective of students and convocation senators, who would be less familiar with the institution's structures and processes as a result of not working within the institution and dealing with policies and procedures on a daily basis in the way that faculty and staff do. In particular, participants commented that many student and convocation senators do not necessarily understand the various steps and committees that proposals coming before the senate go through before finally ending up at the senate.

\section{Discussion}

While the number of participants in our study is not large, it represents a significant portion $(8$ of $64 ; 12.5 \%)$ of the population, and likely presents an accurate reflection of senators' views on the senate's effectiveness. Though the results of the study are not generalizable to other institutions-as each institution has their own context, culture, and specifics of academic governance-the questions we asked participants could be used to elicit information on the perceived effectiveness of the senate and subsequent improvements to other institutions' governance structures.

It seems, based on the responses, that this institution's senate is not particularly different from the national average reported in Jones et al. (2004) or Pennock et al. (2015). If we assign a value of 0.5 to the "yes and no" answer, the positive responses to the direct question of whether or not the institution's senate is an effective decision-making body total 3.5 out of 8 responses, or $43.75 \%$, which is similar to the $44 \%$ response obtained in 1998-2000 by Jones et al. (2004).

The fact that such a large contingent feels that the senate is not effective is worrisome. While no governance body is perfect, if fewer than half the people in the room at any given meeting feel that the senate is effective, it speaks to a need to pursue the issue further, particularly in a case where there was not a single positive response that was not accompanied by caveats.

There appears to be a disconnect between the administrators sitting on the senate ex officio and the faculty and students that make up the bulk of the body. Although this is a relatively small sample size, both ex officio senators responded that the senate was effective, as did one senator with an academic appointment, while another senator with an administrative appointment responded "yes and no"; the remaining respondents, all without administrative appointments, responded that the senate was not effective. This may speak to differences in opinion regarding the senate's role within the institutional community, or individual senators' relationships to the senate, but it merits further investigation. The senators seem to agree with the majority of their constituency group when compared to the responses in Pennock et al. (2015), with the primary difference being the response of the convocation senator, who replied in the negative. 
The senate's role as the ultimate (or occasionally penultimate) academic governance authority is a legal requirement of the University Act. That some senators dispute that the senate actually makes those decisions creates concern; if there is a perception that the senate has only a rubber-stamping role, it drives people away from participating and ends up reinforcing that rubber-stamping role. Because senators feel that there needs to be more "young blood" amongst the faculty senators, ensuring that there is room for discussion and decision-making is vital, as is the recognition of service on the senate through institutional tenure and promotion policies. Expanding the room for discussion would also serve as example-setting for student senators on how to appropriately enter the conversation and could lead to increased engagement and participation among student senators.

Although the institution's senate is smaller than many across Canada (with 77 being the average senate size found in Pennock et al. (2015)), it was described as too large, a comment echoed in Pennock et al. (2015), where one third of participants indicated that senates were too large regardless of size. The primary concern cited by these participants was the number of individuals on the senate who did not contribute directly, though there was also a view that areas that affect the academic enterprise were not included in the senate or in the senate's oversight.

Additionally, the senate committees appear to be ripe for re-evaluation. Nearly all participants had concerns about at least one committee in terms of effectiveness, including concerns about the structure of particular mandates and the way committees conduct their business, in addition to the number of committees. While only one participant spoke directly about having too many senate committees, a number of others made comments about similar problems, such as finding individuals willing to serve on senate committees and potentially burning students out by having too many committees with too few student senators.

There appear to be significant connections between various issues brought up by participants. Ensuring the highest level of participation among faculty and students senators, for example, can be connected to levels of debate, positions on committees, and perceptions of the senate as a decision-making body. Conversely, those perceptions are connected to positions on and mandates of committees, delegated authority, and engagement among faculty. Issues brought up during the interviews that could be more easily addressed, such as the use of delegated authority and the level of debate at the senate are, in many ways, symptoms of larger issues that exist within the senate. Addressing these smaller issues would assist in addressing the more overarching issues, but ultimately, the larger issues will need to be addressed.

The senate has been allowed to evolve organically in those areas under the institution's control since the institution was founded. Committees have been created as needs have arisen, with small tweaks to mandates and memberships as necessitated by particular events. Efforts to streamline the business of the senate have resulted in "committees for almost single tasks," and attempts to ensure senators are not overly burdened by their service have resulted in senate committees with high numbers of ex officio members. In a narrow view, the fundamental purpose of the senate is to fulfill its obligations under the University Act, while the wider view is one of the senate as the institutional steward that the Act envisages. The institution's senate is fulfilling the narrow role; from the participants' responses, it appears that whether the wider role is being properly served is-at best-up for debate. 
Few changes have occurred to the institution's senate since the interviews were completed in 2012. One committee has been eliminated, with its responsibilities folded into those of another committee, and several other committees have had their terms of reference updated. If we compare the current situation, based on the comments from participants, to the existing literature, it suggests that the existing governance arrangements could be improved. Looking through Trakman's (2008) lens, it would appear that the institution's senate assumes that good governance simply happens, rather than as the result of intentionally attempting to achieve that goal. There has been little recent reflection on the appropriate structures and processes, either by the governing or the governed; there have also been few (if any) crises in the recent past that have compelled such a review or a change. The participants' comments reflect a governance model in line with Bradshaw and Fredette's (2009) current governance processes-internally-focused, short-term, and reactive-while participants' suggestions could help the institution move towards a more strategic, proactive, integrated, and cohesive model, as Bradshaw and Fredette envisioned. While the participants' suggestions for change might not be enough to create that movement on their own, taken in concert with Trakman's suggestion on reflection with intent, the suggestions could begin the movement towards a more strategic governance model for the institution.

The participants' comments suggest that the institution's community has a nuanced view of the senate's legitimacy, as contemplated by Hartley (2003). While one participant stated directly that the institution's senate had credibility, comments about whether the senate really makes decisions and about its effectiveness suggest that not everyone in the community agrees. In the context of Ackroyd and Ackroyd's (1999) work, which suggests that institutional governance arrangements need to correspond to the institution's goals and context, it is evident that the current senate structure and processes do not reflect the institution's goals. For example, the comment about committees not keeping up with evolving strategy suggests governance has been allowed to lag behind. While the mandate of the University Act (1996) hampers some potential changes, little has been done to ensure cohesion between the institution's constituent parts.

Many of the comments and suggestions for change detailed in our study suggest that senators are waiting for leadership to begin making changes. There seems to be nearuniversal agreement, at least among the participants, that change is needed, even if not everyone agrees on the appropriate scope of that change. Given that even those who responded that the senate is an effective decision-making body suggested an overall review, it may be that all that is missing at this point is for someone to suggest such a review, and for someone to lead it.

Academic governance in Canada is a field that has been under-researched, and our study highlights many potential research directions. One includes looking at the process of academic governance reflection and renewal and the effects of utilizing existing governance renewal practices in an academic setting. Finally, research into best practices within a particular context may provide a way forward to increasing the effectiveness of academic governance nationally, while keeping in mind that effectiveness is a process, not an endpoint, and that each institutional context has its own challenges and opportunities. 


\section{References}

Ackroyd, P., \& Ackroyd, S. (1999). Problems of university governance in Britain: Is more accountability the solution? International Journal of Public Sector Management, 12(2), 171-185. doi:10.1108/09513559910263480

Berkowitz, P. (2010, November 8). University senate - is it still useful? University Affairs. Retrieved from http://www.universityaffairs.ca/

Birnbaum, R. (1989). The latent organizational functions of the academic senate: Why senates do not work but will not go away. The Journal of Higher Education, 60(4), 423-443.

Bradshaw, P., \& Fredette, C. (2009). Academic governance of universities. Journal of Management Inquiry, 18(2), 123-133. doi:10.1177/1056492608326320

Creswell, J. W. (2012). Educational research: Planning, conducting, and evaluating quantitative and qualitative research (4th ed.). Boston, MA: Pearson Education.

Hartley, M. (2003). The promise and peril of parallel governance structures. American Behavioral Scientist, 46(7), 923-945.

Jones, G. A., Shanahan, T., \& Goyan, P. (2001). University governance in Canadian higher education. Tertiary Education and Management, 7(2), 135-148. doi:10.1023/A:1011333915176

Jones, G. A., Shanahan, T., \& Goyan, P. (2004). The academic senate and university governance in Canada. Canadian Journal of Higher Education, 34(2), 35-68. Retrieved from http://journals.sfu.ca/cjhe/index.php/cjhe/article/view/183456/183409

Jones, G. A., \& Skolnik, M. L. (1997). Governing boards in Canadian universities. The Review of Higher Education, 20(3), 277-295. doi:10.1353/rhe.1997.0003

Minor, J. (2003). Assessing the senate. American Behavioral Scientist, 46(7), 960977. doi:10.1177/0002764202250122

Pennock, L., Jones, G. A., Leclerc, J. M., \& Li, S. X. (2015). Assessing the role and structure of academic senates in Canadian universities, 2000-2012. Higher Education. Advance online publication. doi:10.1007/s10734-014-9852-8

Province of Ontario, Royal Commission on the University of Toronto. (1906). Report of the Royal Commission on the University of Toronto. Toronto, ON: L. K. Cameron.

Trakman, L. (2008). Modelling university governance. Higher Education Quarterly, 62(1-2), 63-83. doi:10.1111/j.1468-2273.2008.00384.x

University Act, Revised Statutes of British Columbia. (1996, c. 468). Retrieved from the Queen's Printer for British Columbia website: http://www.bclaws.ca/

\section{Contact Information}

Patrick Lougheed

Plaid Consulting

patlougheed@gmail.com 
Patrick Lougheed is partner and co-founder at Plaid Consulting, and currently lives and works within the traditional and unceded territories of the Coast Salish peoples. He graduated from Simon Fraser University's postsecondary Educational Leadership master's program in 2012. He works to bridge the gap between data and information within higher education student and academic services.

Michelle Pidgeon's ancestry and family are from Newfoundland and Labrador and she currently lives and works within the traditional and unceded territories of the Coast Salish peoples. She is an associate professor in the Faculty of Education at Simon Fraser University and teaches primarily in Educational Leadership graduate programs and is passionate about higher education, student services, and Indigenity. 